\title{
Efektivitas Program Karantina 30 Hari dalam Menghafal Alquran 30 Juz di PP Miftahul Huda Wonosobo
}

\section{Rifqi Muntaqo, Nely Fitriana}

Fakultas Ilmu Tarbiyah dan Keguruan UNSIQ Wonosobo,Jawa Tengah rifqimuntaqo@unsiq.ac.id

DOI: http://dx.doi.org/10.29240/alquds.v2i2.536

Submitted: 2018-08-30 | Revised: 2018-10-11 |Accepted: 2018-11-13

\begin{abstract}
This study aims to explain the concept and implementation of a 30-day quarantine program in memorizing Alquran 30 juz at the Miftahul Huda Islamic boarding school in Wonosobo. This research approach is qualitative, while the physical techniques of the data are; Win affairs, interviews and documentation. By analyzing data, students/students have enthusiasm and enthusiasm when learning memorization takes place, students/students are able to meet the target every day. Students/students are always disciplined and disciplined in activities, most students/students meet the target targets on time.This study concluded that the 30-day quarantine program at PP Miftahul Huda Siwatu Wonosobo can significantly fulfill the target of the 30-juz Alquran memorization of the santri.
\end{abstract}

Keywords:Effectiveness, Quarantine Program, Memorizing Alquran

\begin{abstract}
Abstrak. Penelitian ini bertujuan menjelaskan konsep dan pelaksanaan program karantina 30 hari dalam menghafal Alquran 30 juz di PP Miftahul Huda Siwatu Wonosobo. Pendekatan penelitian ini adalah kualitatif, adapun teknik pengumpulan datanya yakni; observasi, wawancara dan dokumentasi. Berdasarkan analisis data, Santri memiliki gairah dan semangat pada saat pembelajaran menghafal berlangsung, Santri mampu memenuhi target setiap harinya. Santri selalu tertib dan disiplin dalam kegiatan, sebagian besar Santri mampu menyelesaikan target dengan tepat waktu. Penelitian ini berkesimpulan bahwa program karantina 30 hari di PP Miftahul Huda Siwatu Wonosobo secara signifikan dapat memenuhi target hafalan Alquran 30 juz para santri.
\end{abstract}

Kata kunci:Efektivitas, Program Karantina, Menghafal Alquran

\section{Pendahuluan}

Tujuan dari beragama salah satunya adalah tercapainya kebahagiaan hidup, baik di dunia maupun akhirat. Oleh karena itu, Islam sebagai agama, memiliki 3 konsep utama yakni aqidah, syariah dan akhlaq yang ketiganya 
memberikan garansi bagi pemeluknya bahagia dunia dan akhirat. Adapun salah satu sumber ajaran agama Islam adalah Alquran, yang didalamnya berisi permasalahan aqidah, syariah, dan akhlak, untuk mentransformasikan doktrindoktrin tersebut Allah SWT memberikan tugas ini kepada baginda agung Muhammad SAW sekaligus memberikan tauladan yang sebenarnya sesuai ajaran Islam.

Umat Islam memiliki kewajiban untuk membaca, memahami dan mempraktekkan apa yang diajarkan dalam Alquran. Kesempurnaan Alquran sebagai pedoman hidup manusia memiliki keterkaitan erat dengan ilmu pengetahuan sebagai bekal menjalani hidup. ${ }^{1}$ Alquran sebagai muara kebenaran. Menurut Kuntowijoyo, ${ }^{2}$ Alquran adalah premis kebenaran. Karena Alquran adalah sumber ajaran Islam yang terjamin keasliannya oleh Allah SWT, dan dalam penjagaannya pun Allah tidak memberikan beban kepada siapapun termasuk para Nabi. Di antara bukti tersebut, lebih dari 14 abad semenjak diturunkannya Alquran, ia tetap asli sebagaimana saat diturunkan, juga sebagaimana ia disampaikan oleh Rasulullah SAW kemudian diterima oleh para sahabat, setelah itu disampaikan ke generasi setelah mereka, dari satu generasi ke generasi yang lain dipelihara dalam hati, dibaca dengan lisan, tertulis dalam mushaf, dan dihafal oleh puluhan ribu kaum muslimin. ${ }^{3}$

Umat Islam perlu untuk menghidupkan ayat-ayat Alquran, berbagai metode yang digunakan untuk membaca, memahami bahkan menghafal Alquran. Pada penelitian ini difokuskan pada metode menghafal,yakni suatu metode yang telah lama digunakan umat Islam sebagai media menjaga Alquran. Banyak keutamaan bagi yang menghafal Alquran baik di dunia maupun di akhirat,dalam sebuah hadis disebutkan "Sesunnguhnya Allah akan mengangkat sekelompok kaum dan merendahkan yang lainnya dengan Alquran". "Sebagai contoh, sekarang banyak lembaga-lembaga pendidikan bahkan perguruan tinggi memberikan beasiswa secara cuma-cuma kepada para penghafal Alquran.

Metode hafalan juga digunakan para sahabat Nabi dalam menjaga Alquran, karena sesuai dengan sejarah yang diceritakan bahwa Alquran ditulis diberbagai lembaran, seperti dedaunan, tulang belulang dan sebagainya. Atas izin Allah SWT periode tersebut bisa dilalui oleh para sahabat dengan semakin banyaknya para hafidz-hafidzoh sehingga dapat mewarisi sumber ajaran Islam itu hingga terbukukan. Salah satu motivasi yang dimunculkan dalam benak umat Islam adalah membaca Alquran ibadah. Alquran juga bacaan terbaik umat Islam

${ }^{1}$ M. Quraish Shihab, Membumikan Al-Quran: Fungsi dan Peran Wabyu dalam Kebidupan Masyarakat (Bandung: Mizan Pustaka, 2007), 33.

${ }^{2}$ Muhammad Zainal Abidin, Paradigma Islam Dalam Pembangunan Ilmu Integralistik: Membaca Pemikiran Kuntowijoyo (Jakarta: Aswaja Pressindo, 2016), 125.

${ }^{3}$ Abdul Hamid, Pengantar Studi Alquran (Jakarta: Kencana, 2006), 26.

${ }^{4}$ Ahmad Salim Badwilan, Cara Mudah Menghafal Alquran (Yogyakarta: Bening, 2010), 10. 
dalam keadaan apapun. Selain itu, membaca Alquran juga menjadi obat dan penawar bagi orang yang mengalami gangguan jiwanya.

Ibnu Mas'ud meriwayatkan tentang seseorang yang sedang mengalami kegelisahan dalam hidupnya, Ibnu Mas'ud memberikan saran: "jika itu penyakit hati yang melandamu sebaiknya kamu perlakukan beberapa hal ini, yakni: pertama, menemui orang yang sedang membaca Alquran lalu dengarkan atau tirulah membaca Alquran dengan kesungguhan hati. Kedua, berkumpul dengan orang-orang saleh seperti dalam pengajian-pengajian yang dapat meningkatkan kualitas imanmu kepada Allah SWT. Ketiga, beribadah kepada Allah dengan sungguh-sungguh. Dengan cara tersebut, diharapkan orang yang sedang mengalami kegundahan hati dapat menjadi tentram dan nyaman.

Berkaitan hal tersebut, urgensi membaca, memahami dan menghafal Alquran yakni umat Islam dapat hidup rukun sesuai yang diajarkan Alquran, bahkan lebih dari itu umat Islam dianjurkan untuk mengajarkannya kembali kepada sesama manusia. Sebagaimana dijelaskan di dalam sabda Rasulullah SAW memberikan pengajaran tentang Alquran adalah pekerjaan yang sangat mulia, yakni:

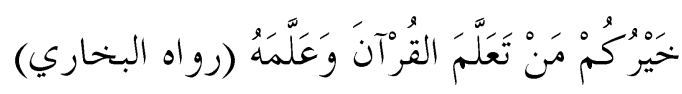

sebaik-baiknya manusia diantara kalian adalah yang mempelajari Alquran serta mengamalkannya. ${ }^{5}$

Dijelaskan pada hadis di atas bahwa orang yang bersedia mempelajari Alquran dan mengajarkannya akan mendapatkan tingkat derajat yang tinggi oleh Allah SWT. Mempelajari di sini dapat diasumsikan bahwa membaca dan memahami, namun untuk menghafalkannya memang membutuhkan kemampuan lebih dari seseorang yang akan menghafalkannya. Sebagaimana yang dilakukan Nabi Muhammad SAW ketika mendapatkan mukjizat Alquran, dimana Nabi membutuhkan kekuatan untuk menerima Alquran dari ayat pertama hingga ayat terakhir. Berkat keteladanan yang diberikan Nabi dalam menjaga hafalan Alquran, sehingga para sahabat termotivasi untuk terus menjaga Alquran hingga akhir hayat. ${ }^{6}$ Sebagaimana firman Allah:

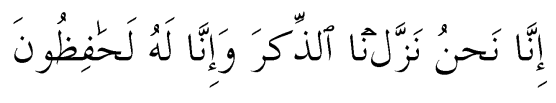

${ }^{5}$ Abi Abdillah Muhammad bin Ismail Al-Bukhari, Al-Jami' Al-Shabih (Mesir: Maktabah Salafiyah, 1403), 6, 192, hadits nomor 5027.

${ }^{6}$ Mustofa Kamal, "Pengaruh Pelaksanaan Program Menghafal Alquran Terhadap Prestasi Belajar Siswa," TADARUS: Jurnal Pendidikan Islam 6, no. 2 (2017): 2-3, http://journal.umsurabaya.ac.id/index.php/Tadarus/article/view/918. 
Sesunggubnya Kamilah yang menurunkan az-D₹ikra (Alquran) dan sesunggubnya Kamilah (Allab SWT) yang benar-benar memeliharanya"

Budaya menghafal Alquran di Nusantara sudah sejak dahulu dipraktikkan kiai, ustad, santri dan pelajar Islam lainnya. Bahkan beberapa pesantren di Indonesia memberikan porsi khusus kepada santrinya untuk menghafal Alquran, seperti ponpes al-Munawwir Krapyak Yogyakarta, ponpes Yanbu'ul Quran Kudus, ponpes Betengan Demak, ponpes Fajrul Falah Pekalongan, ponpes Lukman Hakim Surabaya, dan ponpes lainnya diluar pulau Jawa.

Beberapa pembahasan akademik tentang pentingnya menghidupkan ayat-ayat Alquran dalam kehidupan manusia sehari-hari seperti yang dibahas oleh Sahiron Samsudin dalam penelitiannya, adalah living quran. ${ }^{8}$ konsep tersebut menekankan pemahaman kita pada fungsi dan hikmah Alquran bagi kehidupan manusia. ${ }^{9}$ Dengan demikian, upaya kita sebagai umat muslim memahaminya melalui epistemologi bayani, epistemologi burhani dan epistemologi irfani dapat tercapai dengan sempurna. Diperjelas lagi oleh Yusuf, living quran ${ }^{10}$ suatu ilmu yang berada pada kajian yang tidak absolute namun untuk orang islam living quran tetap pada tempat yang absolute.

Pentingnya menghidupkan ayat-ayat Alquran sebagaimana dijelaskan dalam konsep living quran, manusia mampu memahami dan memperlakukannya dalam rangka meraih hidayah yang terdapat didalam Alquran, dimana pada era globalisasi ini kegiatan-kegiatan living quran banyak dilakukan oleh masyarakat seperti yasinan, tahlilan, mujahadah, zikir dan sebagainya untuk mengagungkan nilai-nilai Alquran. Pemaknaan dan perlakuan semacam itu hanya dipandang sebagai salah satu bentuk perlakuan yang dapat diberikan terhadap Alquran, dan pemaknaan serta perlakuan inilah yang kemudian menjadi objek kajian itu sendiri. Tentu saja, peran dan kedudukan Alquran sebagai kitab tidak bisa diabaikan begitu saja. Namun, yang dimaksud dengan Alqurandi sini bukan lagi mutllak kitabnya, tetapi juga tafsir dan pola-pola perilaku yang didasarkan pada tafsir atas ayat-ayat dalam Alquran tersebut.

Berbicara tentang Alquran banyak hal yang dapat dijadikan objek studi, baik dari segi sebab-sebab turunnya ayat, penafsirannya, bahasanya maupun baca

${ }^{7}$ Q.S Al- Hijr ayat 9

${ }^{8}$ Living Alquran adalah sebuah teks Alquran yang hidup di lingkungan masyarakat, sedangkan untuk mengumpulkan hasil dan interpretasi dari masyarakat dikumpulkan dalam the living tafsir. Sahiron Syamsuddin, "Ranah-Ranah Dalam Penelitian Alquran Dan Hadis," in Metodologi Penelitian Living Alquran Dan Hadis, by Muhammad Mansur (Yogyakarta: Teras, 2007), 18-19.

${ }^{9}$ Richard Martin, ed., Approaches to Islam in Religious Studies (Oxford: Oneworld, 2001), 23 24. 2007), 8 .

${ }^{10}$ Muhammad Mansur, Metodologi Penelitian Living Alquran Dan Hadis (Yogyakarta: Teras, 
tulis Alquran, tergantung kepada tujuan yang akan dicapai. Tetapi, yang penulis bahas disini adalah bagaimana menghafal Alquran secara mudah dan cepat. Karena rata-rata mindset orang, menghafal Alquran itu sulit dan memerlukan waktu yang begitu lama. PP Miftahul Huda Siwatu Wonosobo merupakan sebuah lembaga yang memberikan pendidikan bagi anak-anak dari TK, SD, MTS sampai SMK. Pendidikan di pondok ini merupakan perpaduan antara pendidikan agama dan pendidikan formal, salah satu pendidikan agamanya yang unggul adalah program karantina menghafal Alquran 30 hari/sebulan.

Para santri yang masuk di PP Miftahul Huda Siwatu Wonosobo untuk mengikuti program karantina menghafal Alquran sebulan sangatlah heterogen, dari berbagai umur dan juga berbagai kalangan. Namun di sini para santri akan melakukan pembelajaran yang sama dan menggunakan metode yang sudah ditentukan yaitu menggunakan metode Yadain. Untuk itu, penelitian ini akan diarahkan untuk menekankan proses pembelajaran menghafal cepat.

Beberapa penelitian terdahulu, seperti yang dilakukan oleh Mustofa Kamal. Menghafal Alquran pada usia muda sangat penting untuk dimasukkan dalam kegiatan sehari-hari anak didik dengan tujuan kegiatannya berisi dengan kegiatan yang positif yakni hafalan Quran. Dengan demikian, orang tua dan guru memiliki peran penting dalam membentuk karakter peserta didik dengan nilainilai positif dan berguna bagi nusa, bangsa dan agama. Dari penelitiannya dapat disimpulkan, yakni terdapat pengaruh dari proses menghafalkan Alquran yang positif terhadap menigkatknya prestasi dan kualitas belajar siswa. Hal tersebut ditunjukan dari $\mathrm{r}$ hasil perhitungan sebesar 0,681 lebih besar dari pada tabel $\mathrm{r}$, baik dari pada taraf signifikasi 5\% (0,514) maupun 1\% (0,641). Kemudian penelitian yang dilakukan oleh Husna Rosidah, kemampuan menghafal Alquran siswa MTS YAPI Pakem Yogyakarta dari paradigma behaviorisme menyatakan sangat berpengaruh terhadap prestasi belajar bahasa arab.

Sehingga dapat dipahami bahwa penelitian yang dilakukan oleh penulis merupakan hal baru, diawali dengan pemahaman program karantina tersebut kemudian dijalankan oleh pengasuh atau pendidik dan diikuti para santri di PP Miftahul Huda Siwatu Wonosobo, dengan beberapa permasalahan penelitian yang akan diangkat adalah bagaimana pemaknaan konsep dan pelaksanaan sekaligus problematika program karantina 30 hari dalam menghafal Alquran 30 juz di PP Miftahul Huda Siwatu Wonosobo 2018?.

Dalam penelitian ini, jenis penelitian yang digunakan adalah penelitian lapangan, suatu penelitian yang dilakukan di lapangan. Dengan kata lain, penelitian lapangan yaitu metode penelitian dengan menganalisis dan menyajikan fakta secara sistematik tentang keadaan objek penelitian. Data dan fakta yang didapat pada objek penelitian yaitu efektivitas program karantina 30 hari dalam menghafal Alquran 30 juz di PP Miftahul Huda Siwatu Wonosobo. 
Metode analisis pengolahan data penelitian ini adalah penelitian kualitatif, dimana penulis tidak menggunakan data statistik dalam pengumpulan dan analisis data. Data yang dibutuhkan dalam penulisan ini adalah data kualitatif. ${ }^{11}$ Penelitian ini menggunakan pendekatan deskritif. Pendekatan deskritif merupakan suatu penelitian dimaksudkan memotret kegiatan yang ada, alamiah maupun rekayasa dari manusia. ${ }^{12}$

Peneliti dapat memperoleh data primer dari lapangan langsung khususnya dari objek penelitian, yaitu bisa dari pengasuh PPMiftahul Huda SiwatuWonosobo, pengurus PPMiftahul Huda SiwatuWonosobo, ustad-ustazah PPMiftahul Huda Siwatu Wonosobo. Adapun data tambahan diambil dari kumpulan-kumpulan berkas hasil rapat atau data lain yang sekiranya mendukung penelitian ini. Penulis dalam melakukan pengumpulan data menggunakan observasi, ${ }^{13}$ wawancara, dan dokumentasi. ${ }^{14}$ Sedangkan analisis data menggunakan reduksi, display ${ }^{15}$ dan menyimpulkan data. ${ }^{16}$

\section{Konsep Tahfizhul Alquran}

Kemudian kegiatan menghafal diartikan sebagai suatu upaya aktif untuk memasukkan informasi ke dalam otak, sedangkan mengingat adalah upaya aktif untuk mengeluarkan informasi ke dalam otak. Menghafal dan mengingat merupakan aktifitas otak yang menghasilkan reaksi kimia dan elektris di dalam otak lebih banyak dibandingkan aktifitas membaca, berbicara, dan kegiatan sejenisnya, sehingga banyak yang menyatakan bahwa menghafal dan mengingat merupakan puncak dari segala aktifitas otak, karenanya sering disebut bahwa apalah artinya pengetahuan tanpa adanya memory atau "what is knowledge without memory?". Kegiatan memori yang terdiri atas 2 (dua) tahapan tadi dapat digambarkan sebagai berikut:
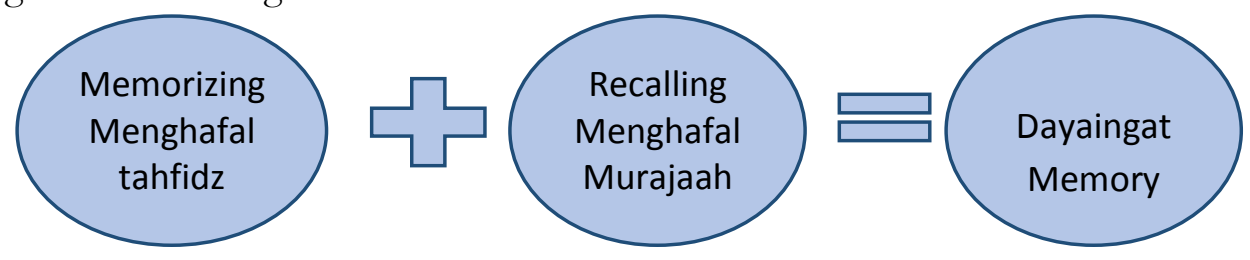

Permasalahannya, kita sering merasakan dalam menghafal pada umumnya adalah susah dalam menghafal dan mudah untuk lupa. Penyebab dari persoalan ini diantaranya karena selama ini kita cenderung melakukan proses

${ }^{11}$ Sumadi Suryabrata, Metodologi Penelitian (Jakarta, 1995), 18.

${ }^{12}$ Nana Shaodih Sukmadinata, Metode Penelitian Pendidikan (Bandung: Remaja Rosdakarya, 2013), 72.

${ }^{13}$ Sutrisno Hadi, Metodologi Research (Yogyakarta: Andi Offset, 2004), 151.

${ }^{14}$ Suharsimi Arikunto, Prosedur Penelitian Suatu Pendekatan Praktek (Jakarta: Bina Aksara, 2002), 22.

${ }^{15}$ Sugiyono, Metode Penelitian Kuantitatif, Kualitatif (Bandung: Alfabeta, 2014), 247.

${ }^{16}$ Ibid., 247.249 . 
memori hanya bertumpu pada satu aktifitas memori, yakni menghafal atau menyetorkan hafalan (memorizing/tahfizhh), sedangkan kegiatan kedua yakni kegiatan mengingat atau memanggil hafalan (recalling/muraja'ab) tidak kita lakukan. Akibatnya, kita hanya bersusah payah menyetorkan hafalan ke otak tanpa tahu cara memanggilnya kembali dari otak, sehingga pada saat diperlukan untuk mengingat, kita lupa begitu saja, padahal kita menghafalnya berulang kali. $^{17}$

Beberapa metode menghafal Alquran, antara lain; Pertama, Menghafal Sendiri, beberapa tahapan yang harus dilalui dalam metode menghafal sendiri, antara lain; a) Memilih mushaf Alquran yang ukurannya sudah disesuaikan dengan kesukaan. b) Melakukan persiapan menghafal, yakni niat, berwudhu dan bersuci dengan sempurna, serta memilih tempat yang nyaman untuk berkonsentrasi. c)Melakukan pemanasan dengan membaca beberapa ayat Alquran sebagai pancingan agar jiwa lebih tenang dan lebih siap menghafal. d) Memulai langkah awal dalam hafalan, yaitu mengamati secara jeli dan teliti ayatayat yang akan dihafalkan sehingga ayat-ayat tersebut terekam dalam hati. e) Memulai langkah kedua dalam hafalan, yaitu mulai membaca secara binnadhar (melihat) ayat-ayat yang akan dihafalkan dengan bacaan tartil dan pelan. Bacaan ini diulang sebanyak lima sampai tujuh kali atau lebih banyak, bahkan sebagian calon Huffazh ada yang mengulang sampai 50 kali. f) Memulai langkah ketiga dalam hafalan, yaitu memejamkan mata sambil melafalkan ayat yang sedang dihafalkan. Langkah ini juga diulang berkali-kali sampai benar-benar yakin sudah hafal dengan sempurna. g) Langkah terakhir adalah tarabbuth atau menyambung, yaitu menyambung secara langsung ayat-ayat yang telah dilafalkan sambil memejamkan mata.

Kedua, Menghafal Berpasangan, metode ini dilakukan oleh dua orang Huffazh secara bersama-sama. Hafalan dimulai setelah mereka menyepakati ayat-ayat yang akan dihafalkan. Langkah-langkah yang ditempuh dalam metode ini adalah sebagai berikut; a) Memilih kawan menghafal yang cocok dan menentukan surat serta waktu yang telah disepakati bersama. b) Saling membuka mushaf Alquran pada bagian ayat yang akan dihafalkan, lalu salah satu dari keduanya membaca ayat tersebut, sedangkan yang lain mendengarkan dengan serius dan berusaha merekam bacaan di dalam otaknya. Setelah selesai, kawan yang tadinya mendengarkan ganti membaca mushaf yang dipegangnya, sementara yang lain mendengar dengan sungguh-sungguh. Setelah itu, yang jadi pendengar mengulang ayat tersebut tanpa melihat. Kemudian kawan yang satunya juga melakukan hal yang sama. Proses ini diulang beberapa kali sampai keduanya yakin telah berhasil menghafal ayat tersebut. c) Dilanjutkan dengan

${ }^{17}$ Kurnia Wijaya Erwin, Magic Memory Alquran (Bandung: Pulpen Publishing, 2015), 1-3. 
praktik tarabbuth, yaitu menyambung ayat-ayat yang telah berhasil dihafalkan. d)Saling menguji hafalan diantara keduanya.

Menurut Ahsin Wijaya metode menghafal Alquran, ${ }^{18}$ diantaranya: a) Metode Wahdah, yaitu menghafal satu persatu terhadap ayat-ayat yang hendak dihafalkannya. b) Metode Kitabah, yaitu penghafal terlebih dulu menulis ayatayat yang akan dihafalkan pada secarik kertas yang telah tersedia. c) Metode Gabungan, yaitu gabungan antara metode wahdah dan metode kitabah, hanya saja pada kitabah lebih berfungsi untuk uji coba terhadap ayat yang telah dihafalkan. d) Metode Jama'/tallaqi, yaitu cara menghafal yang dilakukan secara kolektif yang dipimpin oleh seorang instruktur. Metode ini dilakukan dengan membaca satu atau dua ayat secara bersama-sama dipimpin oleh instructor (tutor). Metode Talaqqi/jama' adalah suatu cara belajar dan mengajar Alquran dari Rasulullah kepada para sahabat dan kemudian diteruskan ke generasi selanjutnya hingga saat ini. Metode ini terbukti paling lengkap dalam mengajarkan bacaan Alquran yang paling benar dan mudah diterima oleh semua kalangan. ${ }^{19}$

\section{Potret PP Miftahul Huda}

Yayasan karantina tahfizh Alquran merupakan lembaga yang bergerak dibidang akselerasi menghafal Alquran sebulan 30 juz. Didirikan pada tanggal 27 ramadhan $1436 \mathrm{H}$ tepatnya 25 Juli 2014. Saat ini telah ada 43 mitra karantina tahfizh se-Indonesia yang menyelenggarakan program karantina tahfizh Alquran dengan metode Yadain. Salah satu mitra karantina tahfizh Alquran nasional adalah mitra Wonosobo yang meliputi karantina tabsin sepekan, karantina tahfizh sepekan menghafal Alquran 5 juz, karantina tahfizh dua pekan menghafal Alquran 10 juz, karantina tahfizh sebulan menghafal Alquran 30 juz. Program ini diadakan agar peserta bisa fokus menyetorkan hafalan Alquran dengan ikhtiar bimbingan intensif selama 10-13 jam per hari selama sebulan. Peserta yang mengikuti program karantina ini adalah calon hafidz-hafidzah dari berbagai provinsi di Indonesia dan beberapa negara tetangga yang memiliki niat ikhlas, usia tidak dibatasi, lulus tes seleksi, sehat jasmani dan rohani, melengkapi persyaratan administrasi dan siap mengikuti seluruh program karantina, peserta disini akan mendapatkan fasilitas berupa Alquran, tas karantina, alat tulis, penginapan, makan 3 kali dalam sehari, laundry, liburan, seragam wisuda, pendampingan 10-13 jam/hari, DVD Dokumentasi, foto dokumentasi, syahadah dan wisuda. ${ }^{20}$

18 Ahsin W. Al-Hafidz, Bimbingan Praktis Menghafal Al-Qur'an (Jakarta: Bumi Aksara, 2003), 19

${ }^{19}$ Ibid., 14.

${ }^{20}$ Wawancara dengan lurah pondok program karantina SiwatuWonosobo, Mbak Puput Alhz, minggu 20 Mei 2016, di Pondok Pesantren Program Karantina Tahfidz Sebulan Siwatu Wonosobo 
PP Miftahul Huda adalah nama sebuah yayasan yang didirikan pada tahun 1982. Yayasan ini berdiri karena rasa keprihatinan KH Ghozaly (alm) dan keluarga melihat semakin merosotnya sikap dan karakter anak-anak zaman sekarang bahkan dari segi keilmuan ajaran Islam pun semakin tidak berkualitas akibat tergerus perkembangan teknologi yang destruktif tanpa pembinaan dari lingkungan masyarakat sekitar. PP Miftahul Huda ini berdiri mula-mula hanya menyediakan pendidikan non formal yaitu pesantren salaf yang pengkajiannya hanya kitab kuning saja, perkembangannya sangat lambat saat itu, untuk menyikapi hal tersebut, perlunya generasi milenial untuk memantaskan dirinya dan bersiap untuk menghadapi perkembangan globalisasi yang semakin canggih dengan teknologinya. ${ }^{21}$

Kebutuhan untuk menumbuhkan karakter Islami yang kafah inilah, pengasuh pesantren membangun sebuah pendidikan pesantren yang berkolaborasi dengan pendidikan formal agar masa depan anak-anak yang dikhawatirkan wali murid/santri tidak terjadi, anak-anak dapat ijazah formal dan non formal. Pendidikan yang pertama dirintis adalah SD, TK, MTS, lalu SMA, setelah mempertimbangkan berbagai kendala, yayasan ini mengadakan program tahfizhul Quran. Setelah program dijalankan yaitu anak-anak sekolah dan menghafal Quran ternyata setiap tahunnya tidak menghasilkan hasil yang signifikan, yang artinya sangat lambat sekali.

Untuk itu beliau mencari-cari metode untuk percepatan, sejak bertahuntahun lamanya hingga akhirnya beliau selalu memohon ketika haji/umrah dan alhamdulillah berkat kegigihan beliau dalam berdoa dan ikhtiar akhirnya menemukan metode Yadain Litahfizhil Quran dan sistem percepatan dalam menghafal Alquran. Metode tersebut beliau respon dengan sepenuh hati tanpa keraguan sedikitpun apalagi setelah mengikuti Training Of Trainer yang diselenggarakan pada tanggal 23 Juni 2016. Dan mulai saat itu beliau mulai bermitra dengan Yayasan Karantina Tahfizh Alquran Nasional.

\section{Program Karantina Tahfizh Sebulan}

Secara etimologi program adalah rancangan mengenai asas-asas serta dengan usaha-usaha dalam ketata negaraan, perekonomian dan sebagainya yang akan dijalankan, ${ }^{22}$ sedangkan karantina adalah tempat untuk menahan penumpang kapal yang kena penyakit menular. ${ }^{23}$ Jadi program karantina yang dimaksud adalah suatu tempat yang dijadikan sebagai wadah dalam menjalankan berbagai rancangan mengenai asas-asas serta dengan usah-usaha yang akan

\footnotetext{
${ }^{21}$ Wawancara dengan pengasuh Ibu Hj. Yulia lhz, minggu 20 Mei 2016, di Pondok Pesantren Program Karantina Tahfidz Sebulan Siwatu Wonosobo

22 Suharsa, Kamus Bahasa Indonesia (Semarang: Widya Karya, n.d.), 391.

${ }^{23}$ Ibid., 223.
} 
dijalankan oleh pengajar/ustadz dan peserta didik/santri dalam proses menghafal Alquran selama 30 hari.

Model pengajaran karantina tahfizh sebulan pada penelitian ini menitikberatkan penguasaan praktek menghafal, dimana santri dan guru/muadzin saling tatap muka (face to face) dalam keadaan santri menyetorkan hafalan maupun santri sedang membuat hafalan. Guru/muadzin akan mendampingi secara intensif hingga santri dapat memenuhi target $(1$ hari $=1$ juz) dengan alokasi waktu yang sudah dijadwalkan.

Cara pelaksanaannya; Pertama pembukaan pengajian, sebelum guru/muhafidz datang, santri membaca doa dan Asmaul Husna sebagai pembukaan, santri tampak semangat dan bergairah. Kedua pengajian, Guru /muhafidz datang dengan wajah tampak sumringah dan ramah, aura positif terpancar dari raut wajah beliau. Setelah guru/muhafidz datang, santri menyetorkan setoran yang sudah di siapkan sebelumnya yaitu 1-2 atau lebih halaman ke guru/muhafidz masing-masing. setelah setor 1-2 atau lebih halaman, santri mundur untuk membuat setoran lagi (durasi waktu 5-20 menit), apabila sudah jadi hafalannya santri maju kembali. Begitu terus sampai memenuhi target ( 1 hari $=1$ juz). Jadi, apabila santri hanya mampu setor 2 halaman dalam durasi 5-20 menit tersebut, maka santri maju setor 10 kali.

Setiap halaman berlaku kelulusan atas penilaian guru/muhafidz. Guru/muhafidz benar-benar menuntun santri dalam hafalannya sehingga santri manghafalkan Alquran sesuai dengan apa yang diajarkan guru/muhafidz. Hal ini meminimalisir kesalahan tajwid, makborijul huruf dan kesalahan urutan ayat dalam hafalan. Ketiga penutupan pengajian dilakukan bersama dengan dipimpin oleh ustad dan diikuti santri dengan membaca doa penutupan pengajian. ${ }^{24}$

Program tahfizhul Quran ini tidak menggunakan metode khusus, para santri diberikan kebebasan untuk menggunakan metode hafalannya masingmasing namun tetap diberikan batasan atau target yang ditentukan pesantren. ${ }^{25}$ Setelah penulis melalukan wawancara kepada santri, metode yang digunakan santri kebanyakan menggunakan metode tadabur alam,maksudnya adalah merenungi atau menghayati kandungan ayat yang akan di hafal sampai terbayang makna ayat. Asyiknya metode ini, di samping menghafal juga dapat memahami makna ayat sehingga menghafal terasa ringan dan nikmat. Bagi yang belum memahami bahasa Arab, bisa menggunakan Alquran terjemah baik terjemahan biasa atau terjemahan per kata.

Dengan metode imajinasi tadabur ini,diharapkan hafalan santri kuat dan tidak mudah hilang. Metode tadabur ini di karantina tahfizh disebut metode Yadain, sebuah metode yang melatih visualisasi imajinasi tadabur sehingga saat 
ayat dibaca terjemahannya juga dibayangkan. Pengasuh PP Miftahul Huda Siwatu Wonosobo Ibu Nyai Hj. Yulia Alhz selalu memberikan motivasi kepada santri yang dilakukan setiap hari bakda subuh, dengan tujuan agar santri kembali semangat dalam mengikuti program karantina tahfizh sebulan.

Salah satu respon santri yang bernama Sherly berasal dari Pekalongan mengatakan, "dengan adanya program karantina tahfizh sebulan di PP Miftahul Huda Siwatu Wonosobo sangat efektif, karena adanya target dan lingkungan teman-teman membuat kita termotivasi dan semangat. Meskipun awalnya sering menangis, namun di setiap tangisan saya, saya juga teringat tujuan saya menghafalkan Alquran adalah untuk kebahagiaan keluarga dan masyarakat yang membutuhkannya nanti, selalu membayangkan akan memakaikan mahkota untuk kedua orang tua di surga kelak. Dan berkat dukungan serta motivasi dari bu nyai dan teman-teman, alhamdulillah 30 hari khatam".

Program karantina 30 hari dalam menghafal Alquran 30 juz di PP Siwatu Wonosobo dilakukan evaluasi tes praktek setiap hari. Cara pelaksanaanya; pertamapengelompokkan, meliputi; (1) Setiap peserta dikelompokkan berdasarkan hasil seleksi baik secara kemampuan menghafal maupun perolehan juz, (2) Setiap kelompok maksimal 10 peserta 1 muhafidz, setiap kelompok tidak ditentukan oleh guru/muhafidz, tetapi peserta didik/santri memilih sendiri personil dalam kelompok, hal tersebut agar peserta didik/santri mersa nyaman dan tidak nervous dalam melakukan sambung ayat (taqroran) dan simakan partner. Dan (3) Bentuk halaqah, dalam bentuk posisi halaqah setiap kelompok bebas menentukan posisi apapun diantaranya yaitu: posisi saf, posisi berbanjar, posisi melingkar, berpasangan namun peserta didik/santri lebih senang menggunakan posisi melingkar saat sambung ayat (tagroran) dan menggunakan posisi berpasangan saat melakukan simakan partner.

Kedua proses evaluasi, dalam prosesi tersebut beberapa hal yang dilakukan antara lain; Setiap guru/muhafidz menyiapkan rekapitulasi perolehan masing-masing balaqahnya untuk dilaporkan dan dievaluasi oleh ketua dan seluruh muhafidz, hasilnya cukup memuaskan, dari perolehan juz peserta didik/santri rata-rata dapat memenuhi target ( 1 hari $=1$ juz ), dari hasil taqroran dan simakan memang peserta didik/santri banyak yang dituntun/belum lancar, namun hal tersebut wajar, karena kelancaran penghafal Alquran itu sebuah proses. Setelah program karantina tahfizh satu bulan selesai, peserta didik/santri dapat mengikuti program muraja'ah 9 bulan. Evaluasi dilakukan setiap pagi pukul 07:00 s/d 08:00. Bahan evaluasi diantaranya; (1) Perolehan hafalan halaqabnya masing-masing, bentuk halaqabnya ada 2 yaitu: sambung ayat (taqroran) dan simakanpartner, bentuk evaluasi tersebut dilakukan secara bergantian/selangseling setiap hari, apabila hari kemarin menggunakan bentuk sambung ayat (taqroran), maka hari berikutnya menggunakan bentuk simakan partner. (2) K7 (keindahan, kesehatan, kedisiplinan, ketertiban, kebersihan, kerapian, 
keamanan). Dan (3) Reward, peserta yang mampu menyelesaikan 30 juz akan mendapatkan penghargaan. Sudah banyak sekali para santri mendapatkan penghargaan berupa setifikat yang dapat digunakan untuk beasiswa bagi yang ingin melanjutkan pendidikan di lembaga formal dan Punishment. Peserta yang tidak memenuhi tata tertib akan mendapatkan sanksi berupa teguran hingga pengguguran kepesertaan. Alhamdulillah di program karntina tahfizh satu bulan belum pernah ada santri yang mengalami sanksi berupa pengguguran kepesertaan, karena santri disini mempunya niat dan motivasi yang sangat kuat diantaranya santri punya keinginan yang sangat mulia yaitu ingin membahagiakan orang tua, ingin membuat orang tua bangga, dan para santri sangat berpegang teguh bahwa orang yang menghafalkan Alquran dapat memasangkan mahkota di kepala orang tuanya. ${ }^{26}$

\section{Problematika Program Karantina 30 Hari}

Melakukan sesuatu hal atau kegiatan pasti mengalami kendala. Baik pada persiapan sebelum melakukan suatu hal atau kegiatan, ketika dalam melaksanakan ataupun dalam tindak akhirnya. Berdasarkan hasil wawancara, program karantina 30 hari dalam menghafal Alquran 30 juz di PP Siwatu Wonosobo mengalami kendala, diantaranya: Pertama, kurangnya guru penyimak/muhafidz dalam melakukan setoran, karena setiap tahun program karantina mengalami peningkatan yang signifikan yaitu bertambahnya santri. Untuk itu diadakannya perekrutan guru penyimak/muhafidz dari pesantren lain. Kedua, adanya santri yang tidak betah karena tuntutan target yang ada, untuk itu di adakannya kegiatan kultum pagi atau motivasi pagi bakda sholat subuh diisi langsung oleh pengasuh Ibu $\mathrm{Hj}$ Yulia Alhz agar memperkuat semangat para santri untuk mengikuti program karantina 30 hari dalam menghafal 30 juz di PPSiwatuWonosobo. Dan Ketiga, adanya santri yang terserang penyakit demam karena perbedaan cuaca, kebanyakan santri datang dari luar kota bahkan antar pulau, jadi tidak heran kalau ada santri yang terkena demam. Untuk itu,PPSiwatu meningkatakan kualitas yaitu berupa bangunan yang baik dan layak, perlengkapan keseharian: selimut tebal, kasur tebal dsb, kesehatan/alat medis untuk para santri agar santri terhindar dari penyakit apapun.

\section{Analisis Efektivitas Program Karantina 30 hari dalam Menghafal Alquran 30 Juz di PP Miftahul Huda SiwatuWonosobo}

Proses pembelajaran di program karantina tahfizh sebulan pada awalnya santri mengalami kesulitan dalam menghafal, namun sampai bagian tengah pembelajaran santri sudah menikmati pembelajaran, dan mereka kelihatan termotivasi dan semangat. Dalam pengamatan tersebut dihasilkan efektivitas proses diantaranya:peserta didik/santri selalu bergairah dan semangat saat

\footnotetext{
${ }^{26}$ Wawancara dengan pengasuh sekaligus muhafidz ibu Yulia alhz (20 Mei 2018)
} 
pembelajaran menghafal berlangsung, santri mampu memenuhi target setiap harinya, santri selalu tertib dan disiplin dalam kegiatan dan banyak santri mampu menyelesaikan target dengan tepat waktu.

Hasil dari program karantina 30 hari dalam menghafal Alquran di PP Miftahul Huda SiwatuWonosobo, tidak hanya menitik beratkan ketetapan waktu dalam menghafal Alquran, namun juga menggunakan acuan dengan aspek; (1) Kognitif; Perolehan juz, ingatan hafalan dan makhorijul huruf. (2)Afektif; Keindahan, dilihat dari sosial santri dalam asrama kepada lingkungan sekitar, meliputi sosialisasi kepada setiap teman-teman seperjuangan, menghormati guru/muhafidz. Kesehatan, dilihat dari kesehatan santri, yang mempunyai penyakit serius atau penyakit ringan. Kedisiplinan, dilihat dari santri saat menjalankan kegiatan harian. Ketertiban, dilihat dari santri saat menjalankan tata tertib program karantina. Kebersihan, dilihat dari gaya hidup santri sehari-hari. Kerapian, dilihat dari gaya hidup santri dan cara berpakaian. Keamanan, dilihat dari keseluruhan, santri mempunyai masalah kriminal atau tidak.

Peneliti juga mendapatkan data dari setiap angkatan program karantina tahfizh satu bulan yang mampu menghatamkan Alquran dengan tepat waktu:Angkatan pertama jumlah peserta ada 7 peserta, yang mampu mengkhatamkan Alquran dalam waktu 30 hari ada 5 peserta.Angkatan kedua jumlah peserta ada 13 peserta, yang mampu mengkhatamkan Alquran dalam waktu 30 hari ada 11 peserta.Angkatan ketiga jumlah peserta ada 15 peserta, yang mampu mengkhatamkan Alquran ada 15 peserta. Serta pada angkatan keempat jumlah peserta ada 17 peserta, yang mampu mengkhatamkan Alquran ada 15 peserta.

Setelah angkatan keempat program karantina sudah tidak membuka angkatan kembali, karena santri datang di waktu yang tidak bersamaan, jadi apabila ada santri masuk langsung memulai start tanpa menunggu santri yang lainnya. Yang terpenting setiap santri dapat memenuhi target yang ada. Hal ini terjadi karena dari pihak yayasan mengetahui bahwa waktu orang berbeda-beda, kata pepatah "terkadang bunga bermekaran tidak di waktu yang sama".

\section{Kesimpulan}

Berdasarkan hasil penelitian yang dilakukan tentang program karantina 30 hari dalam menghafal Alquran 30 juz di PP Miftahul Huda Siwatu Wonosobo 2018 dapat disimpulkan bahwa konsep program karantina 30 hari dalam menghafal Alquran 30 juz di Pondok Miftahul Huda Siwatu Wonosobo menitikberatkan penguasaan praktek menghafal, dimana santri dan guru/muadzin saling tatap muka (face to face) dalam keadaan santri menyetorkan hafalan maupun santri sedang membuat hafalan. Guru mendampingi secara intensif sehingga santri dapat memenuhi target $(1$ hari $=1$ juz $)$ dengan alokasi waktu yang sudah dijadwalkan oleh pesantren. 
Metode yang digunakan oleh santri di program karantina 30 hari dalam menghafal Alquran ini tidak ditentukan oleh lembaga secara khusus, adapun salah satu metode yang digunakan santri adalah metode tadabur alam atau metode Yadain, suatu metode yang bertujuan merenungi atau menghayati kandungan ayat Alquran yang akan dihafal santri.

\section{Bibliografi}

Abidin, Muhammad Zainal. Paradigma Islam Dalam Pembangunan Ilmu Integralistik: Membaca Pemikiran Kuntowijoyo. Jakarta: Aswaja Pressindo, 2016.

Al-Bukhari, Abi Abdillah Muhammad bin Ismail. Al-Jami' Al-Shabih. Mesir: Maktabah Salafiyah, 1403.

Al-Hafidz, Ahsin W. Bimbingan Praktis Menghafal Al-Qur'an. Jakarta: Bumi Aksara, 2003.

Arikunto, Suharsimi. Prosedur Penelitian Suatu Pendekatan Praktek. Jakarta: Bina Aksara, 2002.

Badwilan, Ahmad Salim. Cara Mudah Menghafal Al-Qur'an. Yogyakarta: Bening, 2010.

Erwin, Kurnia Wijaya. Magic Memory Alquran. Bandung: Pulpen Publishing, 2015. Hadi, Sutrisno. Metodologi Research. Yogyakarta: Andi Offset, 2004.

Hamid, Abdul. Pengantar Studi Al-Qur'an. Jakarta: Kencana, 2006.

Kamal, Mustofa. "Pengaruh Pelaksanaan Program Menghafal Al-Qur'an Terhadap Prestasi Belajar Siswa." TAD ARUS: Jurnal Pendidikan Islam 6, no. 2 (2017). http://journal.umsurabaya.ac.id/index.php/Tadarus/article/view/918.

Mansur, Muhammad. Metodologi Penelitian Living Alquran Dan Hadis. Yogyakarta: Teras, 2007.

Martin, Richard, ed. Approaches to Islam in Religious Studies. Oxford: Oneworld, 2001.

Shihab, M. Quraish. Membumikan Al-Quran: Fungsi dan Peran Wabyu dalam Kebidupan Masyarakat. Bandung: Mizan Pustaka, 2007.

Sugiyono. Metode Penelitian Kuantitatif, Kualitatif. Bandung: Alfabeta, 2014.

Suharsa. Kamus Bahasa Indonesia. Semarang: Widya Karya, n.d.

Sukmadinata, Nana Shaodih. Metode Penelitian Pendidikan. Bandung: Remaja Rosdakarya, 2013.

Suryabrata, Sumadi. Metodologi Penelitian. Jakarta, 1995.

Syamsuddin, Sahiron. "Ranah-Ranah Dalam Penelitian Alquran Dan Hadis." In Metodologi Penelitian Living Alquran Dan Hadis, by Muhammad Mansur. Yogyakarta: Teras, 2007. 